\title{
The Bold and the Beautiful: A Courtois Saladin?
}

Ann KONTOR

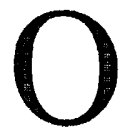

$\mathrm{n}$ a recent episode of Jeopardy!, a contestant correctly identified the Muslim warrior king Saladin for a $\$ 2000$ question. It is surprising that the right answer was given, because when Americans hear the name of Saladin, if they even know who he is, they think of the great adversary of Richard the Lionheart. Would they think of him as a romance hero, an able warrior, brave, valiant, or courtois? History and the West have long had a fascination with Saladin as the definitive leader of the Saracens during the Third Crusade, his fame also expressed in art, literature, and song alike. The famous fourteenth-century Luttrell Psalter presents what purports to be a unique contrasting image of Saladin and Richard jousting. Saladin is depicted with extremely dark skin, a horrible smile on his face, and holding a lance whose tips bears the image of a fierce Muslim warrior. A unique literary work that bears Saladin's name is often overlooked by critics. It is a most curious work extolling the virtues of this twelfth-century hero, and it warrants a further look. Given the fact this text deals extensively with geo-politics, the battle of religious, political, and cultural ideologies, the (mis)construction of the Muslim Other, and the alterity of the Muslim, I think it timely to engage in a discussion of Saladin. This article will examine the unique treatment of Saladin in this fifteenth-century text by a careful examination of key passages, using the lens of Edward Said's Orientalism to see how this 
work exemplifies and subverts the genre of the medieval roman courtois, and how remarkable it is to have Saladin included as its eponymous hero. I hope to show key aspects of how Saladin, beginning as a rather fierce Saracen sultan, after a romantic conquest and his own conversion, ultimately transforms into a quintessentially Christian hero in three different loci: on the battlefield, in the chapel, and in the bedroom, and how it is transported from the Holy Land to France.

Classic epic cycles often involve the conversion and seduction of women. Perhaps the most famous French text of the Middle Ages, $L a$ Chanson de Roland, treats both the depiction and conversion of Muslims. All those who do not adhere to the Christian faith are summarily categorized as Saracens. The gods they honor not only include Allah, but also Apollo and the Gallic god Tervagant. A striking character is Bramimonde, the wife of Charlemagne's enemy, the Muslim king Marsile. She is widowed and taken prisoner by Charlemagne, and he forbids any attempt at her conversion. However, after the utter defeat of the Saracens, Bramimonde loses faith in her $\operatorname{god}(s)$, and one of the last scenes of the work describes her voluntary baptism and her taking the name of Julienne. This epic establishes an orientalist dialectic in which Bramimonde, through her own reasoning, comes to terms with Christianity. In a certain sense, this is a break from the image of crusaders trying to defeat Islam with the sword, and now they try to accomplish their goal by logic. This is an ideological road that Saladin himself will also travel. Another Braslimonde is presented in the thirteenth century Occitan text, Roland à Saragosse. This Braslimonde does many things not expected of a Muslim woman, riding horse and flirting openly with Roland. She insinuates that she could be Christian, and she certainly is not the most devout of Muslims. However, one does see on occasion men who are on the receiving end of conversion stories, and as we shall see in Saladin, it is the Muslim man who is seduced by a Christian woman and who seeks baptism.

Coming to the text Saladin itself that I will be commenting on, it appears as the third and final story situated in a longer work, Jehan d'Avesnes. Though the other two parts of the text may date as early as the thirteenth century, this prose version of Saladin would not have been written later than 1468 (Cook and Crist 61). A poetic version of Saladin's life was alluded to in the fourteenth century Le Deuxième Cycle de la Croisade, being the final poem to unite the other three works in the cycle, but that epic has unfortunately been lost.

The story begins in the twelfth-century Holy Land, where Saladin is waging war on the Infidel invading his country. He takes Christian 
prisoners, Jehan de Ponthieu and Huon Dodequin. Curious about the religion of his captives, he asks them to teach him about their beliefs and occidental customs. In a surprise move, Saladin then decides to travel incognito to the French court to see the life of his enemies first-hand. While there, he has the opportunity to joust his nemesis Richard I, and he wins the admiration of the entire French and English courts as he unseats his lionhearted opponent. The unnamed French queen also becomes very enthusiastic about the handsome foreign prince, and she seduces him. Saladin leaves the French court, only to have the queen follow him back to Jerusalem. The queen's infidelity is quickly learned and she is banished from King Philippe's sight. Saladin continues his struggle to defend the Holy Land from Crusaders, but knowing he is dying, he converts to Christianity and is baptized on his deathbed. His passing brings an abrupt end to the text and leaves the reader with more questions than answers.

The first locus of Saladin's metamorphosis is on the battlefield. In the first third of the text, Saladin exemplifies a traditional Muslim hero, characterized by his bravery and prowess in battle. Chapter VI is typical in this regard, as the text states, ". . .il n'avoit paour d'omme vivant. .." (47). He swears vengeance to Allah for the death of his beloved greatuncle Corsuble. In the thick of the battle, Saladin seizes a lance and slays his enemies on the field in an almost mythical fashion. He consistently has the superhuman ability to outwit and defeat the Crusaders, and ably defends his homeland against the invasion of foreign knights and their ideology. In another episode that would boggle the minds of historians, in Chapter XIX, Saladin's soldiers pledge their undying devotion to him in their quest to invade England. In Chapter XXX, they also rally behind his cry of "Jherusalem!" while fighting in Damascus, invoking the Holy City to remember a previous defeat. However, it proves to be futile, as Saladin loses, a fact he does sadly accept. Having lost not only Jerusalem and Damascus to the Crusaders, but also, as we shall see, Britain and France, and his lady love, not to mention having been mortally wounded after the last battle, will Saladin be able to come to terms with total defeat?

To the victor of the battle go the spoils, and in this aspect Saladin commands the unquestioning respect and love of his people. When Saladin assumes the throne at the beginning of the text, he generously bestows the wealth of the recently-captured Cairo to ease the suffering of his people.

Saladin can indeed be the essence of a chivalrous Muslim prince. But the text also surprises us on multiple occasions, for we see Saladin 
behaving as a model Christian knight as well. A digression from the text is warranted here to mention Edward Said's Orientalism, in which he states that orientalism is nothing more than a Western invention. Everything concerning the East, from Casablanca to Kyoto, is simply lumped under the term "Orient," and it is here that the dichotomy of the Self and the Other is created. As he says, "Islam becomes but an image whose function was not to represent Islam itself, but to represent it for the medieval Christian" (60). The purpose of Muslims in medieval literature was not to be Muslims as they actually were, but rather, they were created to fit the contours of the western imagination. The Other is exoticized and overromanticized in an attempt to create a mirror by which the Self can see its own reflection.

One can clearly see the imposition of Christian values on the historical epitome of a good Muslim warrior-king. One arena that demonstrates this is in battle. Despite the fact that we have seen Saladin be the scourge of Christians in war, his chivalry, by the Western definition, is quite striking. For one thing, the historical rather than the fictional Saladin shows clemency to his Christian prisoners. His contemporary biographer, Baha al-Din Shaddad, recounts one particular episode in which a Christian widow approaches Saladin and beseeches his help in the search for her daughter, who had been kidnapped by Muslim soldiers. Moved to tears, Saladin sends his men in search of the little girl, who find her in the slave market, and she is returned to her mother within the hour (Baha al-Din in Hallam 157).

Turning back to the text, the fictional Saladin is not above sparing the lives of Christian civilians. In Chapter X, during the siege of the fortress of Sur, the women holding the fortress run out of food after eight days. The prettiest of them, designated the Princess of Antioch, had heard tell of "la courtoisie du Turc" (68). She sought an audience with him, and, on bended knee, begged his pity on her and the other women of the fortress, and that Saladin would help assuage their hunger due to a recent famine. Saladin took pity on her and sent provisions from his personal store, then he made a peace treaty with her.

Besides taking pity on these women, Saladin takes an exceptional liking to his two noble captives, Huon Dodequin and Jehan de Ponthieu. In a sense, they become Saladin's disciples, and help him cross the threshold from the battlefield to the second locus of his assimilation, the chapel. Chapter VIII describes how Jehan came to be with Saladin. He chances upon Jehan in battle, surrounded by Saracen soldiers. Saladin proceeds to ask him whether he is a king, duke, or count, but forbade him 
to lie, for he saw Jehan as a "noble home" (56) on the spot. When Jehan reveals that he is merely a French count, Saladin is overjoyed because he knows that Jehan is his mother's first cousin. Saladin's genealogy is explained in Chapter I, and this is certainly one way that the author of the text westernizes Saladin. He comes from both noble French and Islamic families, which lends him even more credibility as the Christian knight that he will eventually become. ${ }^{\prime}$ Saladin then proposes that since he spared Jehan's life, he must stay with him as his devoted prisoner. Saladin further orders Jehan to accompany him to France, which he has dreamed so long of seeing. Two chapters later, Huon Dodequin also falls under Saladin's jurisdiction, having been captured by Saracen soldiers. Saladin was grateful that Huon, a very capable soldier in the crusading army, had fallen into his hands, because he posed a great obstacle to Saladin's fervent desire to possess Jerusalem. As with Jehan, Saladin instructs Huon to remain in his faithful service until the end of his days, and Saladin reiterates his wish to visit France. In turn, Huon is overjoyed to have his life spared and he is even allowed to keep his Christian faith.

After their captures, Huon and Jehan keep their word and do not stray from Saladin's side. In Chapter X, Saladin goes so far as to ask Huon's help to show him "... comment on fait chevaliers a la loy crestienne" (73). Huon reluctantly agrees to show him, so for the first time we hear of Saladin's physique as he has his head washed, his beard trimmed, and he is given a bath. Huon becomes Saladin's fashion consultant, dressing him in a white chemise, the symbolism behind which, he explains, is to live honestly. Saladin is also given a red silk robe to wear, the color of which is to remind him of Christ's blood and to defend the Holy Church from all its enemies. The sultan is also shod in brown shoes, the color of which is to remind him that he is made of dust, to which he will return someday. Saladin is then girded with a white belt for, as Huon reminds him, he is a knight and must be chaste and not to commit any villainy with his body. The ensemble is completed with spurs and a broadsword, the hallmarks of a Christian knight. From a fashion standpoint, Saladin has metamorphosed into a regular crusader garbed in red and white, both of which symbolize martyrdom. Clean and dressed as a typical crusader, Saladin presents a striking figure. Even at this early stage of the text, the exotic Other is slowly becoming the Western Self, which is something that the original fifteenth-century audience may have hoped to identify with. If Saladin represents all that is foreign and mysterious to medieval Europeans, to christianize him is to make him familiar, thus more accessible to the reader. 
Dressed correctly, Saladin sets sail with Jehan and Huon in tow. He asks them to make sure he conducts himself like a Frenchman. Their advice must have served him well, for all the French courtiers remarked that none of the other knights at court were as gracious, handsome, or as young as Saladin. The author then shifts his attention to focus solely on Saladin and his exploits at the French court, his skill in jousting Richard, and winning the queen's affections. Jehan and Huon's supporting rôles are reduced to mere cameo appearances until Chapter XVIII, when Saladin tries to conquer England, and he suspects that Huon and Jehan may have betrayed his military secrets regarding his invasion by alerting the French and English armies of his plans. Saladin realizes in the next chapter that they could not have possibly been traitors, for they stayed right by his side through the thick of the battle. Huon quickly interjects that if Saladin ever believes he betrayed his honor, Huon was ready to fight anyone who challenged his loyalty.

In Chapter XXVI, for reasons not clearly stated in the text, Saladin again questions Huon's loyalty. The setting of the story is back in the Middle East, and Huon seeks permission to briefly visit his wife and children in Mecca. Saladin denies his request, and Huon bitterly retorts that he will fight to prove that he is Saladin's vassal. After a brief duel with two of Saladin's best Muslim fighters, Saladin realizes his fidelity once and for all. Though it breaks his heart to do so, Saladin lets Huon go free (albeit after a hefty ransom) in thanksgiving for his unwavering devotion. Unfortunately, it is Huon's son, aptly named Gérard Bel Armé, who fatally hurled his sword into Saladin's side during the final stand at Damascus.

Jehan and Huon are two interesting minor characters that merit a closer look. Saladin has no two closer friends/confidants in this text, and they present an interesting paradox. Though both prisoners and subject to a Muslim lord, they never renounce their Christian faith. Yet, at the behest of the Muslim prince, they initiate him in the ways of a Christian warrior. At Saladin's insistence, Jehan and Huon then become the catalysts for his final metamorphosis into the consummate Christian. How Saladin rewards his faithful prisoners is also interesting, because it proves that he values the input of his Christian comrades, and that he is chivalrous even to his prisoners. We see the importance of Saladin's family, because Jehan, although accused of treachery, never has to prove his loyalty to the extent Huon does. As a matter of fact, Jehan does not return to Europe like Huon does. Rather, like a faithful servant who has spent so many 
years in service of his good master, he is rewarded with an entire kingdom to govern over.

While not a friend of Saladin, Richard the Lionheart's name is worth mentioning, because Saladin's name will forever be inexorably linked with his. Richard plays a relatively minor rôle in the text, but the author sees it fit to use him as Saladin's mirror, for if the English king is the epitome of all that a good Christian knight is, it is in Richard's reflection that we start to see Saladin emerging as a Christian ruler in his own right. The first time they meet is in Chapter XIV, when Jehan is pointing out various members of the French court. They meet again in the next chapter, when Saladin throws a banquet for the other lords, and again in Chapter XVI, when Saladin's prowess with a lance is too much for Richard, and he unseats him. Saladin's victory causes the others to wonder who the "estrange chevalier" (105) is. But Richard is no fool. He knows that Saladin is a formidable enemy. In an amusing twist to the story, Saladin, advised by Huon and Jehan, decides to conquer England as the most viable way to get his foot into Europe's door and eventually conquer France. When the sultan invades England with 900,000 soldiers, Richard gives thanks to see so many French knights come to his aid, for "il ne doubtoit la puissance du soudan Salhadin" (114). By this point in the text, Richard is no longer the mirror. Though he did not succeed in his tenacious effort to conquer Britain, it is now Saladin who has proven himself a formidable opponent. After the aborted conquest of England, Richard quietly fades out of the story as quickly as he appeared.

Saladin's appearance in the French court brings out the third locus of his transformation: the bedroom. Here it is interesting to see the author use Saladin, the "savage" Other, as a mirror of courtly society. Through his innocent foreign eyes, we see the court with its stringent rules and stuffy courtiers from a fresh perspective. Richard I becomes a mere man to beat in jousting, and the queen is certainly not a paragon of virtue; rather, she is a woman to be conquered, and Philippe is a husband to be cuckolded. Upon his arrival in court, no one knows that Saladin is a Saracen, but rather is known as the "chevalier franc et courtois," which is probably to be expected of any knight jousting in the court of Philippe Auguste. The queen seems to have taken a particular fancy to Saladin. The first mention of her attraction comes in Chapter XIV, at a court marriage. Struck by a fit of lust, she says that Saladin is ". . .le plus bel qu'onques Nature formast" (94). She is frustrated that Saladin cannot read her thoughts and guess her affections. Her desire continues into Chapter XVI, when Saladin is jousting Richard I. The text states: 
“...quant elle aperçut que Salhadin estoit estrangier, considerant qu'elle s'estoit a luy habandonnee, memorative de sa beaulté, advertie de sa grant noblesse et haulte chevalerie, elle laissa son cuer ou il estoit" (109).

It isn't until Chapter XXVII that the queen and Saladin meet again face-to-face, but this time Saladin has the home-court advantage. Having traveled to the Middle East in the company of Philippe, the queen is delighted to once again see her "courtois amy" (148). In a reverie, she convinces herself that no man on earth can compare to Saladin. She says:

...noble homme, riche que plus que prince terrien, vaillant sur tous ceulx quy chevalerie vuellent maintenir, bel par la grace de Nature... gracieux si que pareil a vous n'a en ce monde, amoureux et plaisant plus que dire ne saroye, fleur d'amours, esperance de joye, miroir de prouesse et d'onneur, sage en tous maintiens! (149)

She continues her monologue, sighing that she cannot be alone with her lover, but she will find a way to make this tall, dark and handsome man her own.

Her ruse is an ingenious one, covered in the guise of religion. In Chapter XXVIII, the queen approaches her husband and tells him of a dream she has just had in which she envisioned Saladin's conversion. The king calls his counselors, and the queen persuades them to let her leave and travel to the Acre, whereby she would make pilgrimages to holy sites in Jerusalem, while attempting to convert Saladin. She is granted permission, on the grounds that one of the king's knights, Chauvigny, act as her chaperone. When they reach Jerusalem, the first thing the queen does in Saladin's presence is kiss him multiple times, which deeply disturbs Chauvigny, who decides to keep a closer eye on his charge. When Saladin later learns that the knight is serving as the queen's guide, he feels a strong "mal contempt" (152) for him. Saladin then does something he has yet to do in the text: lie. He tells Chauvigny that, "... se je festoye ... vostre maistresse, car pou avés vous apris se ne sçaves que princez ont de coustume de bienvignier damez sur toutez riens, pour ce que d'elle[s] vient tout honneur et joye" (152). His love for the queen blinds him, and for once we see the valiant soldier stooping to deceit to win her affections.

Chauvigny expresses his concerns of Saladin's intentions to the queen, but she earnestly replies that she is merely trying to convert him. Chapter XXIX begins with the narrator telling of Chauvigny's misgivings about the conversion, and he seriously doubted she even had any intention of returning to France. The French knight entreaties the queen 
for one more audience. Saladin encourages the queen to hear him out, and Chauvigny kidnaps the queen on horseback. Her screams alert Saladin, who takes his soldiers to go after the both of them, but to no avail. The queen is confronted by her husband back in Acre, and he sends her back to her native Aragon in disgrace. Saladin seems powerless to help his lover, but Chauvigny falls into his hands at the end of the chapter as his prisoner. Despite the fact the French soldier has fathered a son by a Saracen woman and that Philippe offered a handsome reward for his safe return, Saladin orders Chauvigny hanged. This is one of the few instances in the text where we see Saladin being less than noble and courtois. Because of the betrayal of Saladin's heart, Chauvigny is not able to enjoy the same fate that Jehan and Huon do. However, his Muslim mistress frees him from prison, and in Chapter XXX, he leads the final charge against Saladin at Damascus, and to French victory.

Another curious twist that the text presents is the anonymity of the queen herself. We know everything about Saladin: his lineage and family, military exploits, friendships, the devotion of his subjects, and his travels. Nothing is hidden from the reader. Though he represents the Muslim Other, the quantity of information given makes him accessible to the reader as a true character. The queen, however, remains a total enigma. At no point in the text is she deigned to be given any sort of name, and is relegated to merely being "the sister or daughter of the King of Aragon."2 Not only is identity of this queen a complete mystery, her motives also remain unclear. The author of the text, while he does say that the queen is enamored of Saladin because of his good looks and accomplishments in jousting, never explains why she goes to such lengths to seduce him, nor is the martial strife between the queen and Philippe ever fully explained.

Love aside, Saladin's reaction to Christianity is rather curious. He spent a good portion of the text plying Jehan and Huon with questions about their customs and their faith. All this seems to foreshadow Saladin's final metamorphosis from pagan into Christian, from the "Other" to the "Self." At the end of the text, it becomes clear that Saladin has lost Jerusalem to the invading European forces. Knowing his end is near and with a sword embedded in him, Saladin has one last audience with some learned clerics to debate religion with them. His curiosity having been satisfied, Saladin asks for a basin. With eyes raised to the heavens, he utters three words which history (and the text) ignore. He makes the sign of the cross and says, "Autant y a il de cy jusquez la, qu'il a de la jusquez a cy" (169). Taking the water and pouring it over his head, Saladin baptizes himself 
and dies, as the text indicates, "a grans regretz" (169). Thus ends Saladin's short but colorful life, and here the text abruptly ends.

In conclusion, Saladin represents a very interesting late medieval text. He has undergone a very long evolution since the Crusades. $\mathrm{He}$ goes from being the bold and beautiful Muslim warrior-king and seductor, to losing his beloved Damascus, and dying without the comfort of his closest friends. The one thing that he has to sustain him in his final moments is his conversion to Christianity. The author of the text uses Saladin as a mirror to Christianity and as a conduit to the French court, transforming him into a courtly and brave version of Richard, who finds his way into the heart of the queen. It is clear that opposites attract in this text, and that the orient "Other" is assimilated into the dominant western paradigm. This story is an example of revisionist history that envisions an alternative literary destiny for our hero, and he does reflect an image of French courtliness and courtoisie.

\section{University of Nebraska-Lincoln}

\section{Notes}

1. Several different alternate family trees between Saladin and the House of Ponthieu were proposed as early as the 13 th century (Crist 200202).

2. In reality, Philippe Auguste's first wife was Isabella of Hainault, but she could not have been the queen in the text, because their divorce was drawn out over the last ten years of Saladin's life (1183-1193), which is when the bulk of the action of the text would have occurred. It wasn't even until the reign of Philippe le Hardi (1270-1285) that an Aragonese queen was even on the French throne.

\section{Works Cited}

Anonymous. Saladin. Ed. by Larry S. Crist. Geneva: Librairie Droz, 1972. Cook, Robert F. and Larry S. Crist. Le Deuxième cycle de la Croisade: deux études sur son développement. Geneva: Librairie Droz, 1972. Hallam, Elizabeth. Chronicles of the Crusades. New York: Salamander Books, 2000.

Said, Edward. Orientalism. New York: Vintage Books, 1978. 